\title{
Charge-Density Induced Discrimination of Halides with a Rigid Dinuclear Copper(II) Complex
}

Md Mhahabubur Rhaman, Mohammad Hasan, Zulfikhar A. Ali, Douglas Powell, Ritesh Tandon, Bryan Wong, Alamgir Hossain

Submitted date: 03/05/2020 - Posted date: 06/05/2020

Licence: CC BY-NC-ND 4.0

Citation information: Rhaman, Md Mhahabubur; Hasan, Mohammad; Ali, Zulfikhar A.; Powell, Douglas; Tandon, Ritesh; Wong, Bryan; et al. (2020): Charge-Density Induced Discrimination of Halides with a Rigid Dinuclear Copper(II) Complex. ChemRxiv. Preprint. https://doi.org/10.26434/chemrxiv.12235973.v1

A rigid dinuclear copper(II) complex $L$ based on furan spacers has been synthesized and studied for its binding interactions with halides by colorimetric studies, UV-Vis titrations, and density functional theory (DFT) calculations. Our results from the titration studies demonstrate that $L$ binds each of the halides in the order of fluoride $>$ chloride $>$ bromide $>$ iodide, correlating directly with the charge density of the respective halide. Fully unconstrained DFT geometry optimizations have been carried out on both the isolated $L$ as well as the anion-bound motifs. Binding energies (DE) were calculated for each of the optimized geometries, yielding an attractive DE of $-92.39,-27.14,-23.16$, and $-13.37 \mathrm{kcal} / \mathrm{mol}$ for fluoride, chloride, bromide, and iodide, respectively, which is in accord with our experimental results. The compound has been further investigated for its biocompatibility on HeLa cells, demonstrating an excellent cell viability up to $500 \mu \mathrm{M}$ concentration.

File list (2)

MSE_R1_cleaned.pdf (1.24 MiB)

view on ChemRxiv - download file

Supporting information_R1.pdf (314.31 KiB)

view on ChemRxiv • download file 


\title{
Charge-Density Induced Discrimination of Halides with a Rigid Dinuclear Copper(II) Complex
}

\author{
Md Mhahabubur Rhaman, ${ }^{a}$ Mohammad H. Hasan, ${ }^{b}$ Zulfikhar A. Ali, ${ }^{c}$ Douglas R. Powell, ${ }^{d}$ Ritesh \\ Tandon, ${ }^{* b}$ Bryan M. Wong, ${ }^{* c}$ Md. Alamgir Hossain*a
}

A rigid dinuclear copper(II) complex $\mathbf{L}$ based on furan spacers has been synthesized and studied for its binding interactions with halides by colorimetric studies, UV-Vis titrations, and density functional theory (DFT) calculations. Our results from the titration studies demonstrate that $\mathbf{L}$ binds each of the halides in the order of fluoride $>$ chloride $>$ bromide > iodide, correlating directly with the charge density of the respective halide. Fully unconstrained DFT geometry optimizations have been carried out on both the isolated $\mathbf{L}$ as well as the anion-bound motifs. Binding energies $(\Delta E)$ were calculated for each of the optimized geometries, yielding an attractive $\Delta \mathrm{E}$ of $-92.39,-27.14,-23.16$, and $-13.37 \mathrm{kcal} / \mathrm{mol}$ for fluoride, chloride, bromide, and iodide, respectively, which is in accord with our experimental results. The compound has been further investigated for its biocompatibility on HeLa cells, demonstrating an excellent cell viability up to $500 \mu \mathrm{M}$ concentration.

\section{Introduction}

Anion recognition is an emerging area of research at the interface of chemistry and biology due to the key roles of anions in chemical, biological, and environmental processes. ${ }^{1,2}$ Complementary receptors could selectively recognize anions with different geometries, sizes, and charges through a variety of non-covalent interactions such as hydrogen bonding, ${ }^{3-6}$ electrostatic, ${ }^{7-10}$ and metal-ligand bonds. ${ }^{11-13}$ In this context, designed receptors functionalized with signaling components are of special interest since they can serve as rapid and costeffective compounds to identify certain guest species, displaying detectable spectroscopic or visible color changes. ${ }^{14-}$ 16 Among the various chemical systems previously studied, transition metal-based molecular receptors have been used to achieve selectivity in anion recognition via Lewis acid-base interactions under neutral conditions. ${ }^{17-29}$ Furthermore, the positive charges on the metal centers provide an increased Coulombic force to attract an anionic guest.

In particular, dinuclear complexes can effectively bind a compatible anion between the two metal centers through metal-ligand interactions. ${ }^{22-31}$ For example, a dinuclear copper(II) complex derived from para-xylyl-based macrocycle was found to bind an oxalate, as well as a succinate anion between the two metal centers. ${ }^{22}$ Beer and coworkers reported that porphyrin-based macrocycles coordinated with zinc(II) functioned as optical sensors for anions in acetone-water solution. ${ }^{25}$ Stang and coworkers synthesized several bowl-

\footnotetext{
a. Department of Chemistry and Biochemistry, Jackson State University, Jackson, MS 39217, USA; E-mail: alamgir.hossain@jsums.edu

b. Department of Microbiology and Immunology, University of Mississippi Medical Center, Jackson, MS 39216, USA

c. Department of Chemical \& Environmental Engineering, Materials Science \& Engineering Program, Department of Chemistry, and Department of Physics \& Astronomy, University of California, Riverside, Riverside, CA 92521, USA; E-mail: bryan.wong@ucr.edu

d. Department of Chemistry and Biochemistry, University of Oklahoma, Norman, OK 73019, USA

Electronic Supplementary Information (ESI) available: [NMR spectra and X-ray structural data]
}

shaped tetranuclear complexes containing ruthenium ions, showing strong affinities for carboxylates in methanol. ${ }^{29}$ Because of the excellent coordinating nature of copper ions, macrocycle-based dinuclear copper complexes have successfully been used for the selective binding of target anions through the utilization of metal-ligand interactions. ${ }^{30-33}$ We previously reported an $\mathrm{N}$-methyl-2,2'-diaminodiethylaminedriven dinuclear copper complex based on $p$-xylyl-based azamacrocycle with a Cu-Cu distance of $7.101 \AA$, which was shown to selectively bind an iodide between the two metal centers. ${ }^{30}$
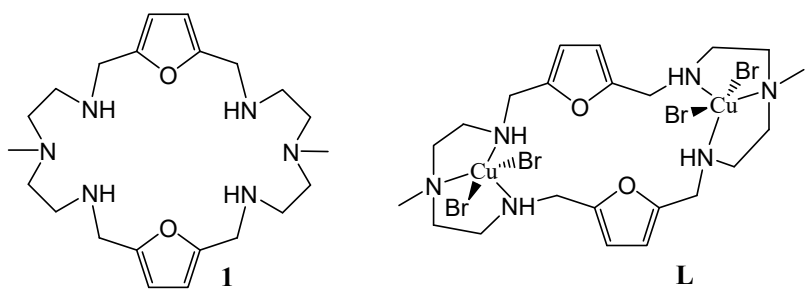

$\mathbf{L}$

Scheme 1. Chemical structures of 1 and its copper complex $\left[\mathrm{Cu}_{2}(\mathbf{1}) \mathrm{Br}_{4}\right], \mathrm{L}$.

As demonstrated, the metal-metal distance in a dinuclear complex may lead to an excellent selectivity for a specific anion due to the perfect match of the guest between two metal centers. ${ }^{22-31}$ It is known that a chelating ligand upon the coordination with metal ions becomes more rigid than its precursor. Therefore, it is possible to manipulate the inner cavity introducing variable metal centers as well as spacers into a macrocycle. In order to reverse the selectivity, we have chosen a furan-based macrocycle that is smaller than the $p$ xylyl-based macrocycle used earlier, ${ }^{30}$ and converted it into a dinuclear copper complex L. Herein, we report that the synthesized L (Scheme 1) with a Cu-Cu distance of $5.439 \AA$, exhibits significant interactions for halides, exhibiting a binding trend with fluoride $>$ chloride $>$ bromide $>$ iodide, which directly correlates with the charge density of the respective halide, with fluoride being the most strongly bound and iodide being the least. 


\section{Results and discussion}

\section{Synthesis}

The synthesis of the macrocyclic amine 1 was made through a condensation reaction of $\mathrm{N}$-methyl-2,2'-diaminodiethylamine with 2,5-furandicarboxaldehyde, following a literature procedure. ${ }^{24}$ The dinuclear copper(II) complex $\mathbf{L}$ was obtained from the reaction of 1 with two equivalents of $\mathrm{CuBr}_{2}$ in a methanol-water mixture (Scheme 1). Crystals suitable for X-ray analysis were grown by the slow evaporation of the complex in a water-methanol mixture ( $v / v, 1: 1)$. However, our numerous attempts to grow $\mathrm{X}$-ray quality crystals of $\mathbf{L}$ with halides were unsuccessful.

\section{Crystal Structure Analysis}

The $X$-ray diffraction analysis of $\mathbf{L}$ revealed that the complex was crystallized in the monoclinic space group $P 2 / C$ having the molecular formula of $\mathrm{C}_{22} \mathrm{H}_{38} \mathrm{Br}_{4} \mathrm{Cu}_{2} \mathrm{~N}_{6} \mathrm{O}_{2} .4\left(\mathrm{H}_{2} \mathrm{O}\right)$. ₹ Two copper(II) ions are coordinated within the macrocycle, each to form the desired dinuclear complex. As opposed to the bowl-shaped geometry observed in the previously reported $p$-xylyl-based dinuclear copper(II) complex,,$^{30,34}$ the inner cavity of $\mathbf{L}$ surrounded by two metal centers and two furan rings adopts a rectangular-type shape (Fig. 1). Each copper(II) ion is coordinated by three $\mathrm{N}$ atoms and two bromides in a squarepyramidal coordination environment, showing a chair conformation as viewed through two aromatic planes. Two $\mathrm{Cu}$ $\mathrm{Br}$ bonds connected to each copper are almost perpendicular, with Cu-Br distances of $2.6450 \AA$ ( $\mathrm{Cu}-\mathrm{Br}_{\text {axial }}$ ) and $2.4361 \AA$ ( $\mathrm{Cu}$ $\mathrm{Br}_{\text {equatorial) }}$. Two axial $\mathrm{Cu}-\mathrm{Br}$ bonds on $\mathrm{Cu} 1$ and $\mathrm{Cu} 1^{i}$ are antiparallel to each other. Each coordinating axial bromide $(\mathrm{Br} 2$ or $\mathrm{Br}^{\mathrm{i}}$ ) forms a strong hydrogen bond $(\mathrm{NH} \cdots \mathrm{Br}=3.525(5) \AA ̊$ ) with an opposite $\mathrm{NH}$, leading the macrocyclic cavity to a rectangular shape. The distance between the two copper(II) atoms is 5.439 $\AA$, which is significantly shorter than the corresponding distance $(7.101 \AA)$ observed in $p$-xylyl-based dinuclear copper(II) complex. ${ }^{30}$ Furthermore, the axial bromides $\left(\mathrm{Br} 2\right.$ and $\left.\mathrm{Br}{ }^{i}\right)$ point outward from the macrocyclic cavity, leading to a vacant site within the cavity that could be accessible for an anionic guest with a comparable size.

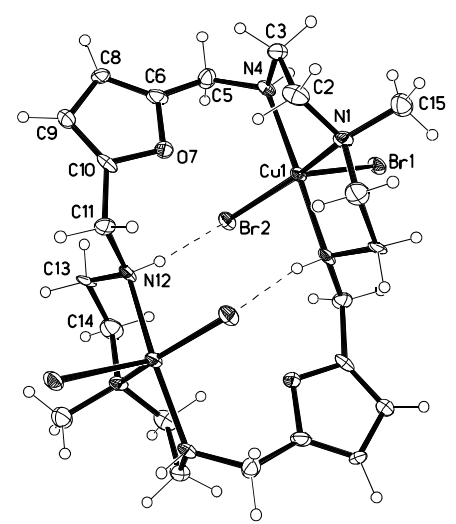

Fig. 1. Perspective views of the crystal structure of $\left[\mathrm{Cu}_{2}{ }^{\prime \prime}(\mathbf{1}) \mathrm{Br}_{4}\right] \cdot 4 \mathrm{H}_{2} \mathrm{O}$. Water are omitted for clarity.

\section{Colorimetric studies}

The receptor $\mathbf{L}$ was found to be insoluble in acetonitrile; thus, we performed the colorimetric study of $\mathbf{L}$ in $\mathrm{CH}_{3} \mathrm{CN}-\mathrm{H}_{2} \mathrm{O}(\mathrm{v} / \mathrm{v}$, 3:1). As shown in Fig. 2, the receptor showed a greenish-blue color in $\mathrm{CH}_{3} \mathrm{CN}-\mathrm{H}_{2} \mathrm{O}$. The addition of one equivalent of each halide to $\mathbf{L}$ showed a noticeable color change, indicating a different absorption. Such a color change is due to the interaction of $\mathbf{L}$ with the respective halide. As shown in Fig. 2, the greenish-blue color of the free $\mathbf{L}$ changed to sky blue for fluoride and light blue for chloride and bromide. A distinct yellowish-green color developed for the addition of iodide to $\mathbf{L}$. A similar color change was previously observed with a dinuclear copper(II) complex ${ }^{30}$ and a tren-based acyclic copper(II) complex ${ }^{35}$

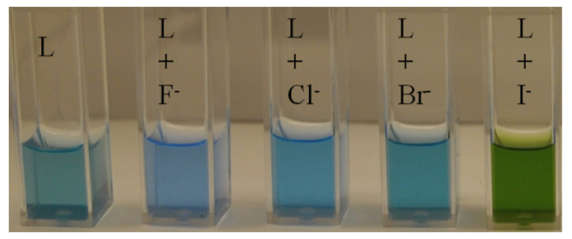

Fig. 2 Colorimetric studies of $\mathrm{L}$ for halides $\left(\mathrm{F}^{-}, \mathrm{Cl}^{-}, \mathrm{Br}^{-}\right.$, and $\mathrm{I}^{-}$in $\mathrm{CH}_{3} \mathrm{CN}-\mathrm{H}_{2} \mathrm{O}(\mathrm{v} / \mathrm{v}, 3: 1)$ at room temperature.

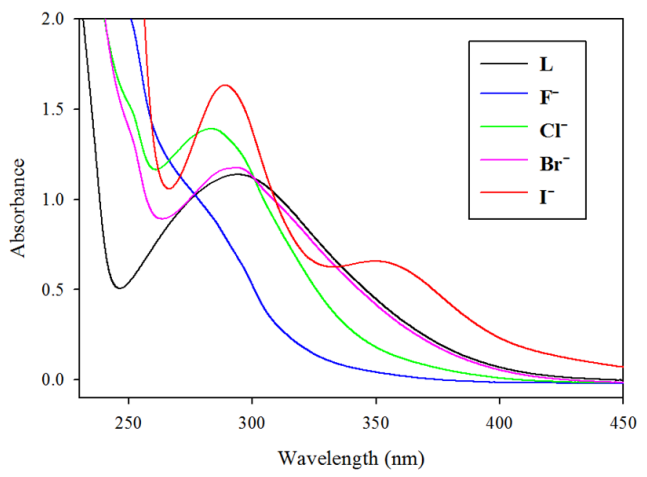

Fig. 3. Change in the absorbance of $\mathbf{L}\left(1 \times 10^{-4} \mathrm{M}\right)$ in the presence of 10 equivalents of different halides in $\mathrm{CH}_{3} \mathrm{CN}-\mathrm{H}_{2} \mathrm{O}(\mathrm{v} / \mathrm{v}, 3: 1)$ at room temperature. 

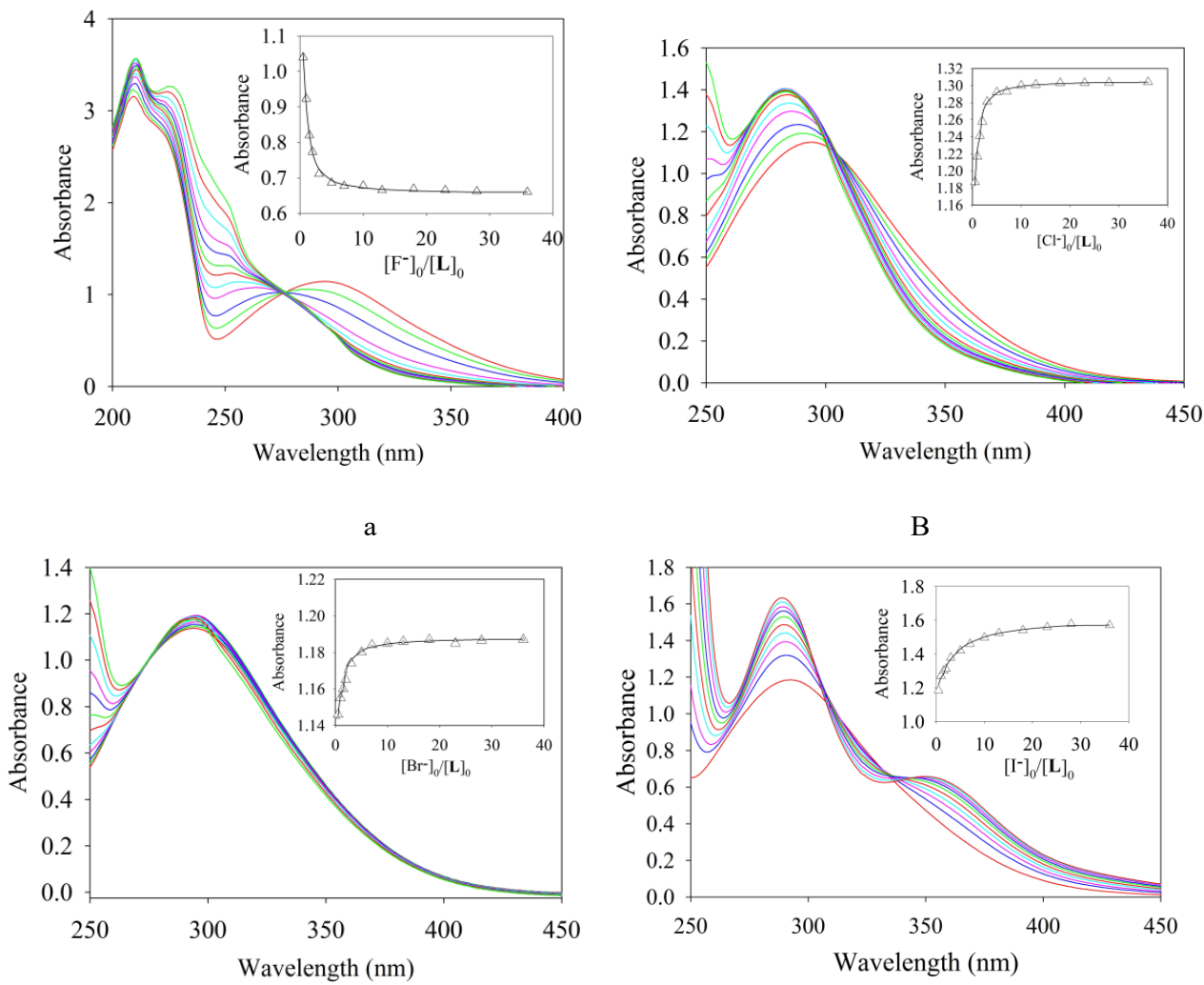

c

$\mathrm{D}$

Fig. 4 Changes in the absorption spectra of $\mathrm{L}\left(1 \times 10^{-4} \mathrm{M}\right)$ with an increasing amount of (a) fluoride, (b) bromide, (c) chloride, and (d) iodide in $\mathrm{CH}_{3} \mathrm{CN}-\mathrm{H}_{2} \mathrm{O}(\mathrm{v} / \mathrm{v}$, 3:1). The titration curves are shown in the insets of each plot.

\section{UV-Vis binding studies}

The binding interactions of $\mathbf{L}$ were initially investigated for various halides $\left(\mathrm{F}^{-}, \mathrm{Cl}^{-}, \mathrm{Br}^{-}\right.$, and $\left.\mathrm{I}^{-}\right)$by $\mathrm{UV}$-Vis studies in $\mathrm{CH}_{3} \mathrm{CN}$ $\mathrm{H}_{2} \mathrm{O}(\mathrm{v} / \mathrm{v}, 3: 1)$. The receptor $L$ showed an absorption band at 294 $\mathrm{nm}$. As shown in Fig. 3, a significant change was observed in the absorption band upon the addition of each of the halides to $\mathbf{L}$. Such a change is attributed to the possible bridging of a halide between the copper centers via metal-halide bonds, ${ }^{30}$ as also supported by DFT calculations (discussed later). This observation is in accord with the results obtained from colorimetric studies. The absorbance of $\mathbf{L}$ at $294 \mathrm{~nm}$ disappeared due to the addition of fluoride. For chloride, bromide, and iodide, the absorption bands were blue-shifted, although the change was small for bromide in terms of wavelength and intensity. The addition of iodide to $L$ resulted in the highest increase in the absorption band, showing a new peak at $349 \mathrm{~nm}$. This observation further supports the sharp colour change observed in colorimetric studies, which is due to the formation of an iodide complex.

The binding constants of $\mathbf{L}$ for halides were determined by UVVis titrations in $\mathrm{CH}_{3} \mathrm{CN}-\mathrm{H}_{2} \mathrm{O}(\mathrm{v} / \mathrm{v}, 3: 1)$. As shown in Fig. 4a, the progressive addition of fluoride to $\mathbf{L}$ resulted in a gradual hypsochromic (blue) shift of $\lambda_{\max }$, showing the progressive decreasing of the absorption intensities (I). An isosbestic point appeared at $275 \mathrm{~nm}$. For chloride, a blue shift was observed (294 to $280 \mathrm{~nm}$ ) with gradual increasing of $I$, exhibiting an isosbestic point at $300 \mathrm{~nm}$ (Fig. 4b). The addition of bromide to the receptor resulted in little increase in the absorption intensity without showing any band shifts (Fig. 4c). On the other hand, the addition of iodide to $\mathbf{L}$ resulted in a different absorption pattern, showing a hyperchromic shift, while the absorption band remained almost unchanged (Fig. 4d). A new band at about $350 \mathrm{~nm}$ appeared, showing two isosbestic points at 308 and $335 \mathrm{~nm}$.

Table 1. Binding constants $(\log K)$ and energies $(E)$ of $L$ with halides.

\begin{tabular}{lll}
\hline Anion & $\log K^{a}$ & $E(\mathrm{kcal} / \mathrm{mol})^{b}$ \\
\hline Fluoride & $4.54(4)$ & -92.39 \\
Chloride & $4.44(3)$ & -27.14 \\
Bromide & $4.27(3)$ & -23.16 \\
lodide & $3.49(2)$ & -13.37 \\
\hline
\end{tabular}

${ }^{a}$ Estimated from UV-Vis titrations, $\mathrm{b}$ Calculated with density functional theory (DFT) using the M06L meta-GGA functional. 


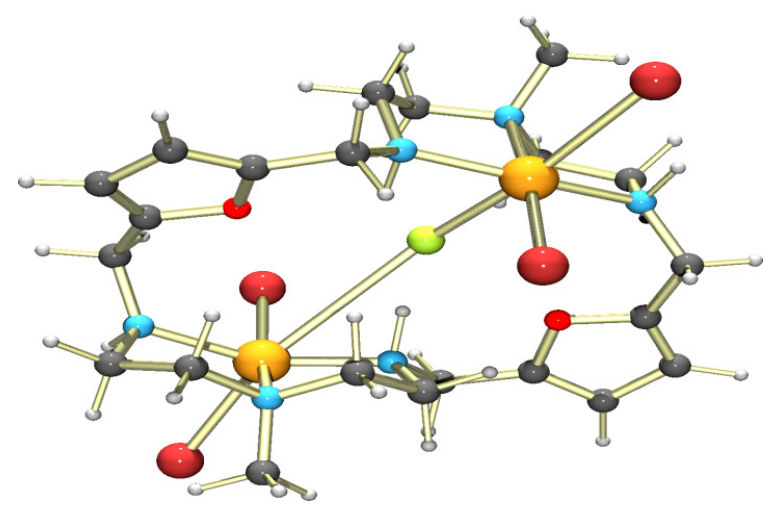

a

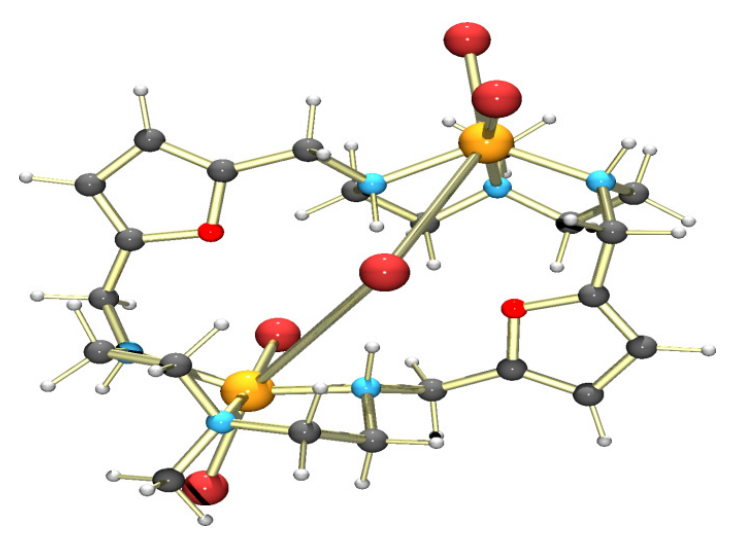

$\mathrm{c}$

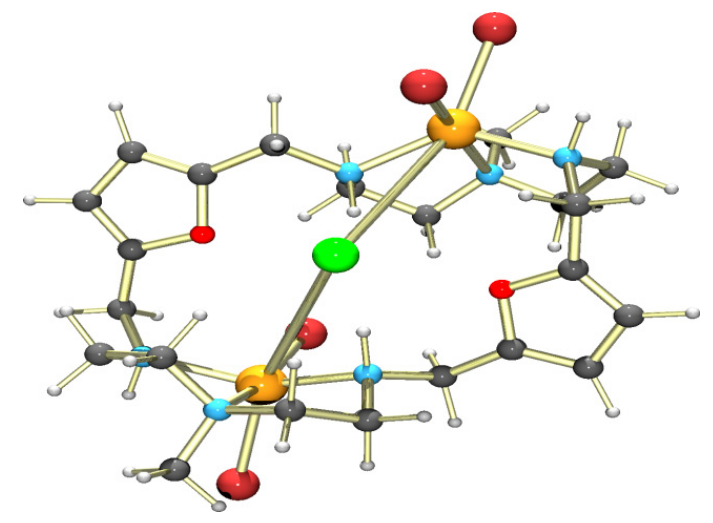

b

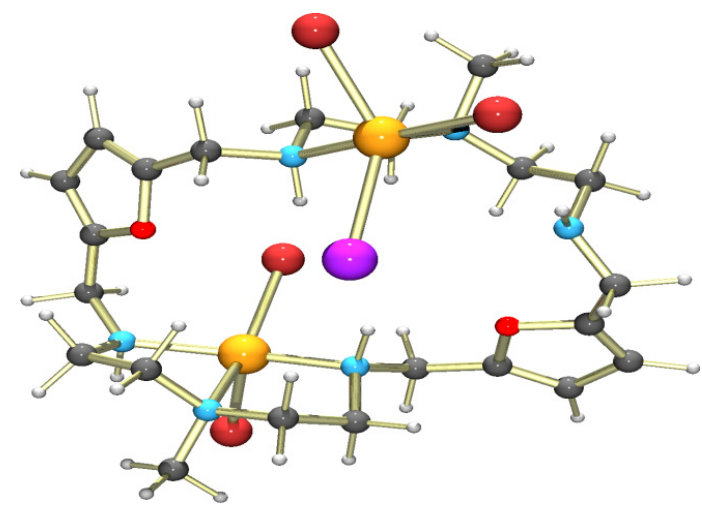

d

Fig. 5. Optimized structures of the complexes of $\mathbf{L}$ with (a) fluoride, (b) chloride, (c) bromide, and (d) iodide, calculated with density functional theory (DFT) using the M06L meta-GGA functional [Colour codes: yellow green = fluoride, green = chloride, dark red = bromide, purple $=$ iodide, gray $=$ carbon, sky blue = nitrogen, red = oxygen and orange = copper].

The distinct response of $\mathbf{L}$ with fluoride (hypochromic shift at $294 \mathrm{~mm}$ ) compared with other halides (hyperchromic shift at $294 \mathrm{~nm}$ ), could be due to the different coordination mode of the attached anions to copper(II) centres during the titration processes. In particular, the attached bromide could be exchanged with a chloride or iodide, which is larger than a fluoride anion, influencing the absorption bands of the complex. The relative changes in the intensity of the absorption band at $294 \mathrm{~nm}$ as a function of the halide concentration were analyzed by a non-linear regression method, providing the best fit to a $1: 1$ binding model (insets in Fig. 4). ${ }^{36}$ The resulting binding constants are listed in Table 1, indicating the highest affinity for fluoride over other halides. The observed binding order $\left(\mathrm{F}^{-}>\mathrm{Cl}^{-}>\mathrm{Br}^{-}>\mathrm{I}^{-}\right)$directly correlates with the charge density of anions $\left(\mathrm{F}^{-}>\mathrm{Cl}^{-}>\mathrm{Br}^{-}>\mathrm{I}^{-}\right)$, thus exhibiting a typical Hofmeister-bias selectivity. ${ }^{37}$ As shown in Table 1 , fluoride is bound only 1.25 and 1.84 times more strongly than chloride and bromine, respectively, demonstrating rather low-to-moderate selectivity. A similar binding trend was reported by Beer and coworkers for triazolium-containing zinc(II) metalloporphyrins, ${ }^{25}$ and by us with a tren-based copper (II) complex. ${ }^{35}$ It is interesting to note that the bite-length ( $\mathrm{Cu}-\mathrm{Cu}$ distance) of $\mathbf{L}$ is $5.439 \AA$, as determined by single $\mathrm{X}$-ray crystallography, which is compatible to fit the tiny fluoride between the two copper(II) centers. The novelty of this work and the advantage of $\mathbf{L}$ compared to our previously $p$-xylylbased dinuclear copper(II) complex is its use of $N$-methyl-2,2'diaminodiethylamine to reverse the selectivity for halides. ${ }^{30}$ The observed selectivity pattern in this study is different than that found in $p$-xylyl-based dinuclear copper(II) complex, which shows selectivity for iodide. ${ }^{30}$ This could be due to the longer bite-length (7.101 $\AA$ ) in $p$-xylyl-based dinuclear copper(II) complex which was a good fit for the larger iodide. 


\section{DFT Calculations}

To shed additional mechanistic insight into the binding motifs of the dinuclear copper complex, we carried out a series of density functional theory (DFT) calculations using the M06L functional. We have specifically chosen the M06L functional for our studies due to its accuracy and widespread use in various supramolecular complexes ${ }^{35}$ as well as noncovalent interactions for large systems. ${ }^{38}$ We used an all-electron polarized 6-31g(d,p) basis set for all atoms except for $\mathrm{F}, \mathrm{Cl}, \mathrm{Br}$, and $\mathrm{I}$, which utilized a larger $6-311 G(d, p)$ basis. The initial geometry of the empty receptor was taken from the refined structure obtained by the X-ray diffraction of L. Fully unconstrained geometry optimizations were carried out on both the isolated receptor as well as the anion-bound motifs. From the optimized geometries, a binding energy was calculated using the following expression: $E=E_{1}+E_{[x]}-E_{[1 . X]}$, where $\mathrm{X}=\mathrm{F}^{-}, \mathrm{Cl}^{-}, \mathrm{Br}^{-}$, or $\mathrm{I}^{-}$. For each of the optimized geometries, the binding energy $(\Delta E)$ was calculated, yielding an attractive $\Delta \mathrm{E}$ of $-92.39,-27.14,-23.16$, and $-13.37 \mathrm{kcal} / \mathrm{mol}$ for the $\mathrm{F}^{-}, \mathrm{Cl}^{-}, \mathrm{Br}^{-}$, and $\mathrm{I}^{-}$anions, respectively (Table 1 ). The numerical results for these binding energies are in accord with the experimental results and directly correlate to the charge density of the halogen anions, with fluoride being the most strongly bound and iodide being the least. We also carried out additional DFT calculations to test other conformational energies of the host, such as geometries where the oxygen atoms of the furan rings were oriented outward from the macrocyclic cavity. Upon full re-optimization of these other configurations, we found that the host reverted back to the geometry where the oxygen atoms still pointed towards the center of the host. Upon closer inspection of these optimized geometries, we found that this configuration was not particularly surprising since the $\mathrm{CH}-\mathrm{CH}$ groups on the furan rings are sterically quite large and actually occupy more space than the lone pairs on the oxygen atom.

The optimized structures of halide-bound complexes of $\mathbf{1}$ are shown in Fig. 5. Each of the chloride and bromide complexes is optimized with a halide bonded to the two copper centers with nearly equal $\mathrm{Cu} \cdots \mathrm{X}$ distances $(\mathrm{Cu} \cdots \mathrm{Cl}=4.12$ and $4.16 \AA$; $\mathrm{Cu} \cdots \mathrm{Br}=$ 4.35 and $4.50 \AA$ ). For the fluoride complex, the anion is bonded with one short $(\mathrm{Cu} \cdots \mathrm{F}=2.33 \AA)$ and one long bond $(\mathrm{Cu} \cdots \mathrm{F}=3.57$ $\AA$ ). The corresponding $\mathrm{Cu}-\mathrm{X}-\mathrm{Cu}$ angles are 149.6, 106.5, and $98.4^{\circ}$, while the distances between the two coppers are 5.72 , 6.63, and $6.67 \AA$ for fluoride, chloride, and bromide complexes, respectively. These observations indicate that the bite-length (the distance between the two copper centers) of the cavity is suitable to fit the tiny fluoride between the two metal centers. On the other hand, the iodide is bound to one copper ion ( $\mathrm{Cu} \cdots$ । $=2.77 \AA$ ) instead of two in the iodide complex (Fig. 5d), indicating that the cavity is too small to host the larger iodide anion.

\section{Cytotoxic Assessment}

The biocompatibility of $\mathbf{L}$ was tested on HeLa cells. A monolayer of HeLa cells was treated with different concentrations (10-750 $\mu \mathrm{M})$ of $\mathbf{L}$ for $\mathbf{2 4}$ hours, and bright-filed images of living cells were acquired (Fig. 6 and 7). Compared to a control solution, no apparent cell death was detected with the treatment of $\mathbf{L}$ up to $500 \mu \mathrm{M}$ (Figure 7). However, some cell death was visualized at concentrations of $750 \mu \mathrm{M}$. For a quantitative measurement of the biocompatibility of L, HeLa cells were treated with $\mathbf{L}$ (10-750 $\mu \mathrm{M})$ for 24 hours, and cell viability was determined using a trypan blue exclusion assay. ${ }^{39}$ In accord with living cell imaging, $\mathbf{L}$ does not have any impact on cell viability up to $500 \mu \mathrm{M}$ of concentration (Fig. 6 and 7). Taken together, these data indicate excellent biocompatibility of $\mathbf{L}$ in mammalian cells up to $500 \mu \mathrm{M}$.
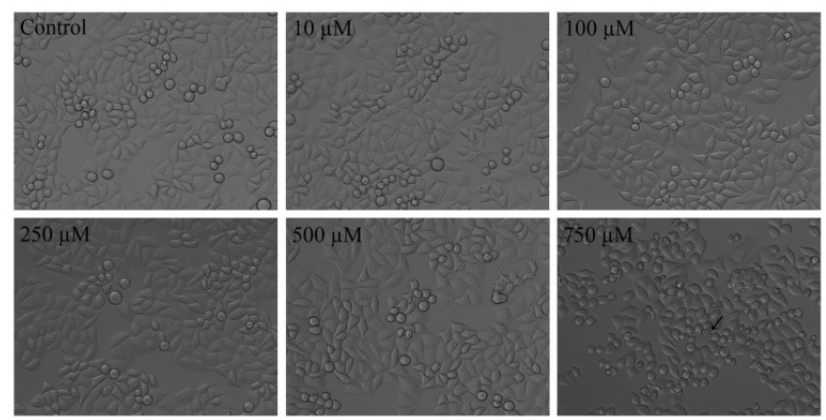

Fig. 6. Bright-field images of HeLa cells treated with L. Cells were either mocktreated (control) or treated with $\mathbf{L}$ for 24 hours at the concentrations specified. The black arrow in the $750 \mu \mathrm{M}$ panel points towards a single dead cell.

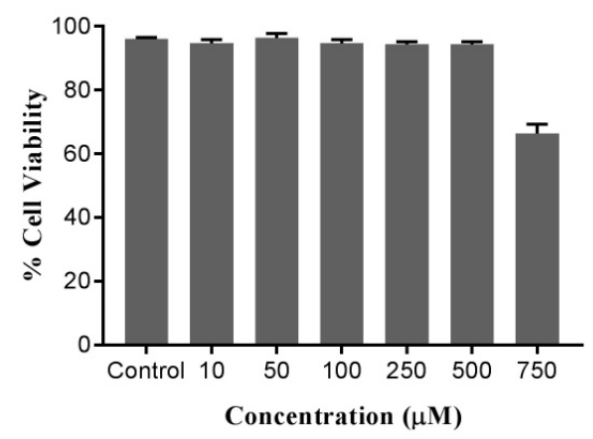

Fig. 7. Effect of $\mathbf{L}$ on mammalian cell viability. HeLa cells were either mocktreated (control) or treated with $\mathrm{L}(10-750 \mu \mathrm{M})$ for 24 hours, and cell viability was quantified using a trypan blue exclusion assay. Error bars denote a standard error of the mean from three independent experiments.

\section{Conclusions}

We have shown that a furan-based dinuclear copper(II) complex strongly binds halides, exhibiting a visual color change in acetonitrile-water. Distinct absorption bands have been observed upon the addition of different halides, suggesting the coordination of a halide to the coordinatively unsaturated copper centers. Results from UV-Vis titrations reveal that the receptor exhibits strong interactions for halides, providing a binding trend of fluoride > chloride > bromide > iodide, exhibiting low-to-moderate selectivity for fluoride over chloride, bromide, and iodide. This binding trend is in accord 
with the charge density of the respective halide, with fluoride being the most strongly bound and iodide being the least. The highest affinity of the receptor for fluoride is due to the best match of the tiny fluoride between two copper(II) centers having a bite-length ( $\mathrm{Cu}-\mathrm{Cu}$ distance) of $5.439 \AA$, as well as the highest charge density of fluoride among the series. Furthermore, the DFT calculations give additional insight into these complexes, showing binding energies for halides in the order of fluoride $>$ chloride $>$ bromide $>$ iodide. The observed variation of the structural and bonding features is consistent with the experimental results. Additionally, the compound does not show any cytotoxic effect on Hela cells at $500 \mu \mathrm{M}$, demonstrating an excellent cell viability on living cells. The strong discriminating capability of this receptor for halides coupled with the biocompatibility towards living cells demonstrates that this compound holds promise as a sensing probe for various biological and chemical applications.

\section{Experimental}

\section{General}

Reagents and solvents were purchased as reagent grades and used without further purification. Nuclear magnetic resonance (NMR) spectra were recorded on a 500 FT-NMR. Chemical shifts were measured in $\mathrm{CDCl}_{3}$ and calibrated with tetramethylsilane (TMS) as an internal reference. Elemental analysis was carried out using an ECS 4010 Analytical Platform (Costech Instrument) at Jackson State University. The absorbance was measured on a UV-2600 UV-VIS spectrophotometer (SHIMADZU). Mass spectral data were obtained in the ESI-MS positive mode on a TSQ Quantum GC (Thermo Scientific).

\section{Synthesis}

1:The synthesis of 1 was carried out following the literature procedure as described earlier. ${ }^{24}$ The dinuclear copper complex L was synthesized from the reaction of $\mathbf{1}(42 \mathrm{mg}, 0.1 \mathrm{mmol})$ with $\mathrm{CuBr}_{2}(45 \mathrm{mg}, 0.2 \mathrm{mmol}$ ) in water. The greenish-blue metal complex thus obtained was separated by filtration, washed by diethyl ether, and dried under vacuum. Yield: $63 \mathrm{mg}, 72 \%$. Anal. Calcd. for $\mathrm{C}_{22} \mathrm{H}_{34} \mathrm{Br}_{4} \mathrm{Cu}_{2} \mathrm{~N}_{6} \mathrm{O}_{2}$ : C, 30.68; $\mathrm{H}, 3.98 ; \mathrm{N}, 9.76$. Found: C, 30.73; H, 4.01; N, 9.82. Recrystallization of the complex in water-methanol $(1: 1, \mathrm{v} / \mathrm{v})$ provided X-ray quality crystals after two weeks. The dinuclear copper(II) complex was characterized by a single-crystal $\mathrm{X}$-ray diffractometer.

\section{X-ray Crystallography}

The crystallographic data and details of data collection for $\left[\mathrm{Cu}_{2}(\mathbf{1}) \mathrm{Br}_{4}\right] .4 \mathrm{H}_{2} \mathrm{O}$ are given in Table S1-S2. Intensity data were collected using a diffractometer with a Bruker APEX ccd area detector and graphite-monochromated MoK $\alpha$ radiation $(\lambda=$ $0.71073 \AA$ A),${ }^{40}$ The structure was solved by direct methods and refined by full-matrix least-squares methods on $F 2 .{ }^{41}$

\section{UV titration studies}

Association constants of $\mathbf{L}$ were determined by UV-Vis titrations using a UV-VIS Spectrometer (UV2600). All the measurements were performed by titrating $\mathrm{L}$ with $\left[n-\mathrm{Bu}_{4} \mathrm{~N}\right]^{+} \mathrm{X}^{-}\left(\mathrm{X}-\mathrm{F}^{-}, \mathrm{Fl}^{-}, \mathrm{Br}^{-}\right.$ and $\left.\mathrm{I}^{-}\right)$in acetonitrile-water mixture $(3: 1, \mathrm{v} / \mathrm{v})$ at $25^{\circ} \mathrm{C}$. Initial concentrations of $\mathbf{L}$ and anions were $1 \times 10^{-4} \mathrm{M}$ and $2 \times 10^{-2} \mathrm{M}$, respectively. Each titration was performed via 13 measurements by varying the [anion $]_{0} /[\mathbf{L}]_{0}$ ratio from $0-36$, and the association constant $K$ was calculated by fitting the change of absorbance with a 1:1 association model using the equation, $\Delta \mathrm{A}=\left([\mathrm{X}]_{0}+[\mathrm{L}]_{0}+1 / K-\left([\mathrm{X}]_{0}+[\mathrm{L}]_{0}+1 / K\right)^{2}-\right.$ $\left.\left.4[L]_{0}[A]_{0}\right)^{1 / 2}\right) \Delta A_{\max } / 2[L]_{0}$ (where $L=$ receptor and $X=$ halide). ${ }^{36}$ The error limit in $K$ was less than $10 \%$.

\section{Computational Studies}

Binding energies and structural optimization of copper complexes were evaluated with density functional theory (DFT) calculations. ${ }^{42}$ All calculations were carried out using the Gaussian 09 package of programs. ${ }^{42}$

\section{Cytotoxicity Assay}

HeLa cells were grown in Dulbecco's modified Eagle's medium (DMEM) (Cellgro, Manassas, VA) supplemented with $10 \%$ fetal bovine serum (Atlanta Biologicals, Flowery Branch, GA), $2 \mathrm{mM}$ L-glutamine, $1 \mathrm{mM}$ sodium pyruvate, $4.5 \mathrm{~g} / \mathrm{ml}$ glucose, and 100 $\mathrm{U} / \mathrm{ml}$ penicillin-streptomycin (Cellgro) at $37^{\circ} \mathrm{C}$ with $5 \% \mathrm{CO}_{2}{ }^{2}$. Cells were seeded in a 12-well plate and incubated until confluency (approximately 24 hours). The media was then replaced with fresh complete media. $\mathbf{L}$ was dissolved in sterile water and filter sterilized. HeLa cells were either mock-treated or treated with $\mathbf{L}$ at a final concentration of $10 \mu \mathrm{M}$ to $750 \mu \mathrm{M}$ for 24 hours. At 24 hours post-treatment, bright-field images of living cells were captured using an inverted Evos-FL microscope (Thermo Fisher Scientific, Waltham, MA). After imaging, cell viability was determined using a TC20 automated cell counter (Bio-Rad Laboratories, Hercules, CA) as previously described. ${ }^{38}$

\section{Conflicts of interest}

There are no conflicts to declare.

\section{Acknowledgements}

The project described was supported by the US Department of Defense (Grant Number W911NF-19-1-0006). Z.A.A. and B.M.W. acknowledge financial support from the Office of Naval Research (Grant N00014-18-1-2740). M.H.H. and R.T. are supported by American Heart Association (Award No. 14SDG20390009).

\section{Notes and references}

₹ Crystal data for $\mathrm{C}_{22} \mathrm{H}_{38} \mathrm{Br}_{4} \mathrm{Cu}_{2} \mathrm{~N}_{6} \mathrm{O}_{2} \cdot 4\left(\mathrm{H}_{2} \mathrm{O}\right), \quad \mathrm{M}=$ 937.37, monoclinic, $a=8.2177(15) \AA ̊ \Omega, b=8.2395(14) \AA, c=23.750(4) \AA ̊ ., \alpha$ $=90^{\circ}, b=93.288(2)^{\circ}, v=90^{\circ}, V=1605.5(5) \AA^{3}, T=100(2) \mathrm{K}$, space group $P 2 / c, Z=2, \mu(M o K \alpha)=0.261 \mathrm{~mm}^{-1}, \mathrm{R} 1=0.0406$. CCDC 1959281.

1 J. W. Steed and J. L. Atwood, Supramolecular Chemistry, 2nd edn., John Wiley \& Sons, Ltd., Hoboken, NJ, 2009. 
2 K. Bowman-James, A. Bianchi, and E. García-Espana, Anion Coordination Chemistry, Wiley-VCH, New York, 2011.

3 in Topics in current chemistry, ed. I. Stibor, Springer-Verlag, Berlin, Editonedn., 2005, vol. 255.

4 J. Yoon, S. K. Kim, N. J. Singh, and K. S. Kim, Chem. Soc. Rev., 2006, 35, 355-360.

5 Y. Hua and A. H. Flood, Chem. Soc. Rev., 2010, 39, 1262-1271.

6 M. A. Hossain, R. A. Begum, V. W. Day, and K. Bowman-James, in Supramolecular Chemistry: From Molecules to Nanomaterials, eds. P. A. Gale and J. W. Steed, John Wiley \& Sons, Ltd., Editonedn., 2012.

7 E. García-España, P. Díaz, J. M. Llinares, and A. Bianchi, Coord. Chem. Rev., 2006, 250, 2952-2986.

8 M. Wenzel, J. R. Hiscock, and P. A. Gale, Chem. Soc. Rev., 2012, 41, 480-520.

9 M. A. Hossain, Curr. Org. Chem., 2008, 12, 1231-1256.

10 F. P. Schmidtchen and M. Berger, Chem. Rev., 1997, 97, 16091646.

11 E. J. O'Neil and B. D. Smith, Coord. Chem. Rev., 2006, 250, 3068-3080.

12 L. Fabbrizzi and A. Poggi, Chem. Soc. Rev., 2013, 42, 16811699.

13 P. Mateus, L. M. P. Lima, and R. Delgado, Polyhedron, 2013, $52,25-42$.

14 L. Basabe-Desmonts, D. N. Reinhoudta, and M. Crego-Calama, Chem. Soc. Rev., 2007, 36, 993-1017.

15 J. S. Kim and D. T. Quang, Chem. Rev., 2007, 107, 3780-3799.

16 E. V. Anslyn, J. Org. Chem, 2007, 72, 687-699.

17 C. J. Harding, F. E. Mabbs, E. J. L. Maclnnes, V. McKee, and J. Nelson, J. Chem. Soc., Dalton Trans., 1996, 3227-3230.

18 V. Amendola, E. Bastianello, L. Fabbrizzi, C. Mangano, P. Pallavicini, A. Perotti, A. M. Lanfredi, and F. Ugozzoli, Angew. Chem., Int. Ed., 2000, 39, 2917-2920.

19 V. Amendola, G. Bergamaschi, A. Buttafava, L. Fabbrizzi, and E. Monzani, J. Am. Chem. Soc., 2010, 132, 147-156.

20 J.-M. Chen, X.-M.Zhuang, L.-Z. Yang, L. Jiang, X.-L. Feng, and T.-B. Lu, Inorg. Chem., 2008, 47, 3158-3165.

21 G. De Santis, L. Fabbrizzi, M. Licchelli, A. Poggi, and A. Taglietti, Angew. Chem., Int. Ed. Engl., 1996, 35, 202-204.

22 S. Carvalho, R. Delgado, M. G. B. Drew, and V. Félix, Dalton Trans., 2007, 2431-2439.

23 F. Li, R. Delgado and V. Félix, Eur. J. Inorg. Chem., 2005, 45504561.

24 M. M. Rhaman, F. R. Fronczek, D. R. Powell, and M. A. Hossain, Dalton Trans., 2014, 43, 4618-4621.

25 L. C. Gilday, N. G. White, and P. D. Beer, Dalton Trans., 2012, 41, 7092-7097.

26 C.-H. Lee, S. Lee, H. Yoon, and W.-D. Jang, Chem.-Eur. J., 2011, $17,13898-13903$

27 M. P. Clares, J. Aguilar, R. Aucejo, C. Lodeiro, M. T. Albelda, F. Pina, J. C. Lima, A. J. Parola, J. Pina, J. S. de Melo, C. Soriano, and E. García-España, Inorg. Chem., 2004, 43, 6114-6122.

28 V. Vajpayee, Y. H. Song, M. H. Lee, H. Kim, M. Wang, P. J. Stang, and K.-W. Chi, Chem.-Eur. J., 2011, 17, 7837-7844.

29 A. Mishra, V. Vajpayee, H. Kim, M. H. Lee, H. Jung, M. Wang, P. J. Stang, and K.-W. Chi, Dalton Trans., 2012, 41, 1195-1201.

30 A. Pramanik, D. R. Powell, B. M. Wong, and M. A. Hossain, Inorg. Chem., 2012, 51, 4274-4284.

31 K. R. Dey, B. M. Wong, and M. A. Hossain, Tetrahedron Lett., 2010, 51, 1329-1332.

32 M. M. Rhaman, A. Alamgir, B. M. Wong, D. R. Powell and M. A. Hossain, RSC Adv., 2014, 4, 54263-54267.

33 N. Singh, H. J. Jung, and D. O. Jang, Tetrahedron Lett., 2009, $50,71-74$.

34 M. M. Rhaman, Douglas R. Powell, M. A. Hossain, ACS Omega, 2017, 2, 7803-781135.

35 A. Haque, R. L. Bolhofner, B. M. Wong, and M. A. Hossain, RSC Adv., 2915, 5, 38733-38741.

36 H. J. Schneider, R. Kramer, S. Simova, and U. Schneider, J. Am. Chem. Soc. 1988, 110, 6442-6448.
37 C. J. Fowler, T. J. Haverlock, B. A. Moyer, J. A. Shriver, D. E. Gross, M. Marquez, J. L. Sessler, M. A. Hossain, and K. Bowman-James, J. Am. Chem. Soc., 2008, 130, 14386-14387.

38 Y. Zhao, C. Huang, M. Kim, B. M. Wong, F. Léonard, P. Gopalan and M. A. Eriksson, ACS Appl. Mater. Interfaces, 2013, 5, 19, 9355-9361

39 M. A. Archer, T. M. Brechtel, L. E. Davis, R. C. Parmar, M. H. Hasan, R. Tandon, Sci. Rep. 2017, 7, 46069.

40 Data Collection: SMART Software Reference Manual, 1998 Bruker-AXS, 5465 E. Cheryl Parkway, Madison, WI 53711, USA. 41 G. M. Sheldrick, Acta Cryst. 2008, A64, 112-122.

42 Y. Zhao and D. G. Truhlar, J. Chem. Phys., 2006, 125, 194101. 43 M. J. Frisch, et al. Gaussian, Inc., Wallingford CT, 2009. 


\section{Supporting Information}

\section{Charge-Density Induced Discrimination of Halides with a Rigid Dinuclear Copper(II) Complex}

Md Mhahabubur Rhaman, ${ }^{\mathrm{a}}$ Mohammad H. Hasan, ${ }^{\mathrm{b}}$ Zulfikhar A. Ali, ${ }^{\mathrm{c}}$ Douglas Powell, ${ }^{\mathrm{d}}$ Ritesh Tandon, ${ }^{c *}$ Bryan M. Wong, ${ }^{c *}$ and Md. Alamgir Hossain ${ }^{a *}$

${ }^{a}$ Department of Chemistry and Biochemistry, Jackson State University, Jackson, MS 39217, USA; E-mail: alamgir.hossain@jsums.edu

${ }^{b}$ Department of Chemical \& Environmental Engineering, Materials Science \& Engineering Program, Department of Chemistry, and Department of Physics \& Astronomy, University of California, Riverside, Riverside, CA 92521,USA; E-mail: bryan.wong@ucr.edu ${ }^{c}$ Department of Microbiology and Immunology, University of Mississippi, Medical Center, Jackson, MS 39216, USA

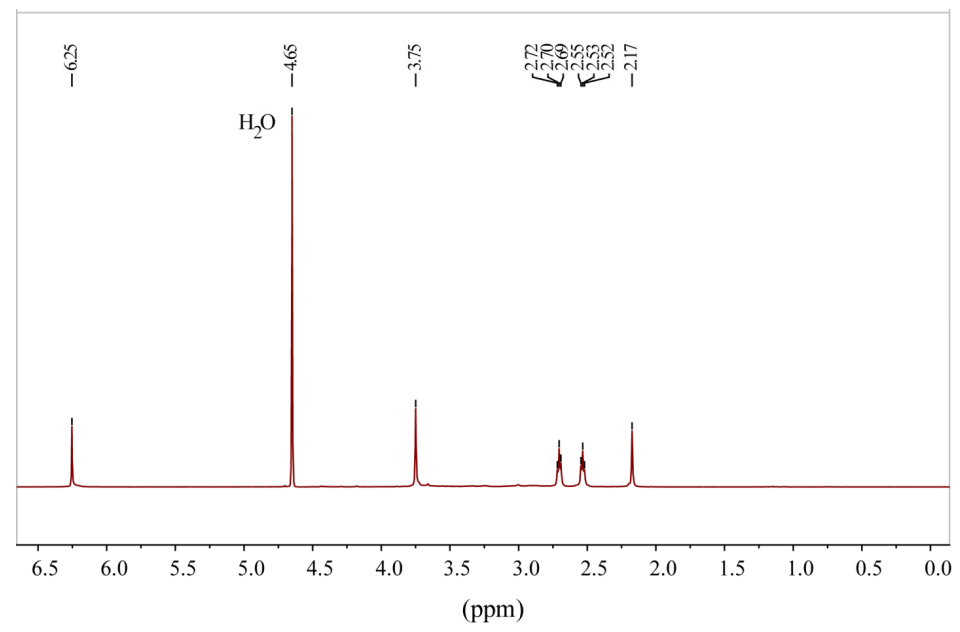

Figure S1. ${ }^{1} \mathrm{H}$ NMR $(500 \mathrm{MHz})$ spectrum of $\mathbf{1}$ in $\mathrm{D}_{2} \mathrm{O}$.

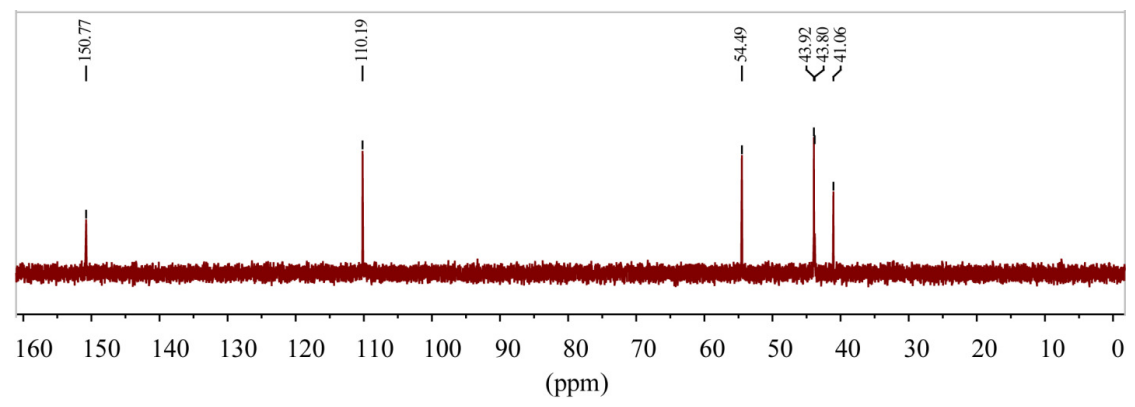

Figure S2. ${ }^{13} \mathrm{C}$ NMR $(125 \mathrm{MHz})$ spectrum of 1 in $\mathrm{D}_{2} \mathrm{O}$. 
Table S1. Crystal data and structure refinement for $\mathbf{L}$

Empirical formula

Formula weight

Crystal system

Space group

Unit cell dimensions

Volume

Z, Z'

Density (calculated)

Wavelength

Temperature

$F(000)$

Absorption coefficient

Absorption correction

Max. and min. transmission

Theta range for data collection

Reflections collected

Independent reflections

Data / restraints / parameters

$w R\left(F^{2}\right.$ all data $)$

$R(F$ obsd data $)$

Goodness-of-fit on $F^{2}$

Observed data $[\mathrm{I}>2 \sigma(\mathrm{I})]$

Largest and mean shift / s.u.

Largest diff. peak and hole
$\left(\mathrm{C}_{22} \mathrm{H}_{38} \mathrm{Br}_{4} \mathrm{Cu}_{2} \mathrm{M}_{6} \mathrm{O}_{2}\right) \cdot 4\left(\mathrm{H}_{2} \mathrm{O}\right)$

$\mathrm{C}_{22} \mathrm{H}_{46} \mathrm{Br}_{4} \mathrm{Cu}_{2} \mathrm{~N}_{6} \mathrm{O}_{6}$

937.37

monoclinic

$P 2 / c$

$a=8.2177(15) \AA \quad \alpha=90^{\circ}$

$b=8.2395(14) \AA$

$\beta=93.288(2)^{\circ}$

$c=23.750(4) \AA$

$\gamma=90^{\circ}$

1605.5(5) $\AA^{3}$

$2,1 / 2$

$1.939 \mathrm{Mg} / \mathrm{m}^{3}$

$0.71073 \AA$

100(2) K

932

$6.348 \mathrm{~mm}^{-1}$

Semi-empirical from equivalents

0.269 and 0.143

2.472 to $25.679^{\circ}$

16798

$2921[\mathrm{R}(\mathrm{int})=0.0569]$

$2921 / 18 / 205$

$w R 2=0.1283$

$R 1=0.0406$

1.005

2500

0.001 and 0.000

0.993 and $-0.786 \mathrm{e} / \AA^{3}$

$$
\begin{aligned}
& w R 2=\left\{\Sigma\left[w\left(F_{\mathrm{O}}^{2}-F_{\mathrm{c}}^{2}\right)^{2}\right] / \Sigma\left[w\left(F_{\mathrm{o}}^{2}\right)^{2}\right]\right\}^{1 / 2} \\
& R 1=\Sigma|| F_{\mathrm{o}}|-| F_{\mathrm{c}}|| / \Sigma\left|F_{\mathrm{o}}\right|
\end{aligned}
$$


Table S2. Hydrogen bonds for $\mathbf{L}$ [in $\AA$ and degrees].

\begin{tabular}{lcccc}
\hline $\mathrm{D}-\mathrm{H} \cdots \mathrm{A}$ & $\mathrm{d}(\mathrm{D}-\mathrm{H})$ & $\mathrm{d}(\mathrm{H} \cdots \mathrm{A})$ & $\mathrm{d}(\mathrm{D} \cdots \mathrm{A})$ & \multicolumn{1}{c}{} \\
\cline { 1 - 3 } $\mathrm{C}(3)-\mathrm{H}(3 \mathrm{~A}) \cdots \mathrm{Br}(1) \# 2$ & & & & \\
$\mathrm{C}(3)-\mathrm{H}(3 \mathrm{~B}) \cdots \mathrm{Br}(1) \# 3$ & 0.99 & 2.95 & $3.782(6)$ & 132.1 \\
$\mathrm{~N}(4)-\mathrm{H}(4) \cdots \mathrm{Br}(1) \# 3$ & 0.99 & 2.88 & $3.622(7)$ & $151(3)$ \\
$\mathrm{C}(5)-\mathrm{H}(5 \mathrm{~B}) \cdots \mathrm{Br}(2)$ & $0.87(5)$ & $2.74(5)$ & $3.524(5)$ & 114.3 \\
$\mathrm{C}(11)-\mathrm{H}(11 \mathrm{~A}) \cdots \mathrm{Br}(2) \# 1$ & 0.99 & 2.88 & $3.408(7)$ & 125.8 \\
$\mathrm{~N}(12)-\mathrm{H}(12) \cdots \mathrm{Br}(2)$ & 0.99 & 2.74 & $3.418(6)$ & $157(6)$ \\
$\mathrm{C}(14)-\mathrm{H}(14 \mathrm{~A}) \cdots \mathrm{Br}(2) \# 4$ & $0.87(5)$ & $2.77(6)$ & $3.588(5)$ & 135.3 \\
$\mathrm{C}(14)-\mathrm{H}(14 \mathrm{~B}) \cdots \mathrm{Br}(2)$ & 0.99 & 2.94 & $3.710(7)$ & 140.9 \\
$\mathrm{C}(15)-\mathrm{H}(15 \mathrm{~B}) \cdots \mathrm{Br}(1) \# 3$ & 0.99 & 2.91 & $3.732(7)$ & 178.9 \\
$\mathrm{O}(1 \mathrm{~S})-\mathrm{H}(1 \mathrm{SA}) \cdots \mathrm{Br}(1) \# 5$ & $0.875(18)$ & $2.500(19)$ & $3.374(5)$ & $177(7)$ \\
$\mathrm{O}(1 \mathrm{~S})-\mathrm{H}(1 \mathrm{SB}) \cdots \mathrm{O}(1 \mathrm{~S}) \# 6$ & $0.87(2)$ & $2.04(4)$ & $2.819(13)$ & $148(7)$ \\
$\mathrm{O}(1 \mathrm{~S})-\mathrm{H}(1 \mathrm{SC}) \cdots \mathrm{O}(2 \mathrm{~S})$ & $0.86(2)$ & $1.99(4)$ & $2.768(9)$ & $150(8)$ \\
$\mathrm{O}(2 \mathrm{~S})-\mathrm{H}(2 \mathrm{SA}) \cdots \mathrm{Br}(1)$ & $0.862(19)$ & $2.58(2)$ & $3.431(5)$ & $167(7)$ \\
$\mathrm{O}(2 \mathrm{~S})-\mathrm{H}(2 \mathrm{SB}) \cdots \mathrm{O}(1 \mathrm{~S})$ & $0.86(2)$ & $2.05(4)$ & $2.768(9)$ & $141(6)$ \\
$\mathrm{O}(2 \mathrm{~S})-\mathrm{H}(2 \mathrm{SC}) \cdots \mathrm{O}(2 \mathrm{~S}) \# 3$ & $0.86(2)$ & $1.99(4)$ & $2.751(15)$ & $146(7)$ \\
& & & &
\end{tabular}

Symmetry transformations used to generate equivalent atoms:

$\# 1-x+1,-y+1,-z \quad \# 2 x+1, y, z \quad \# 3-x+1, y,-z+1 / 2$

$\# 4-x+1,-y,-z \quad \# 5 x, y-1, z \quad \# 6-x, y,-z+1 / 2$ 
Table S3. Cartesian coordinates (in $\AA$ ) calculated with density functional theory (DFT) using the M06L meta-GGA functional for the fluoride complex of $\mathbf{L}$ in the gas phase.

$\begin{array}{lccc}\mathrm{Br} & 3.041700 & 4.613700 & 5.402600 \\ \mathrm{Br} & 2.987200 & 2.183500 & 2.256900 \\ \mathrm{Cu} & 3.988300 & 4.426000 & 2.656400 \\ \mathrm{~N} & 4.935900 & 6.326000 & 2.771100 \\ \mathrm{C} & 6.322200 & 5.901300 & 2.508600 \\ \mathrm{H} & 7.008300 & 6.765200 & 2.521700 \\ \mathrm{H} & 6.318300 & 5.450200 & 1.511000 \\ \mathrm{C} & 6.740800 & 4.864900 & 3.533900 \\ \mathrm{H} & 7.683700 & 4.410100 & 3.212000 \\ \mathrm{H} & 6.918200 & 5.309100 & 4.521300 \\ \mathrm{~N} & 5.694900 & 3.815800 & 3.638800 \\ \mathrm{H} & 5.216400 & 3.899500 & 4.547400 \\ \mathrm{C} & 6.226600 & 2.437900 & 3.564200 \\ \mathrm{H} & 6.872500 & 2.220000 & 4.428400 \\ \mathrm{H} & 5.351100 & 1.777700 & 3.623100 \\ \mathrm{C} & 7.010200 & 2.171200 & 2.333800 \\ \mathrm{O} & 6.497100 & 2.662200 & 1.176800 \\ \mathrm{C} & 8.129000 & 1.438700 & 2.057400 \\ \mathrm{H} & 8.749800 & 0.926200 & 2.780200 \\ \mathrm{C} & 8.286200 & 1.458500 & 0.637900 \\ \mathrm{H} & 9.059500 & 0.974500 & 0.057400 \\ \mathrm{C} & 7.272000 & 2.227000 & 0.143200 \\ \mathrm{C} & 6.850100 & 2.687100 & -1.214300 \\ \mathrm{H} & 7.286400 & 3.663800 & -1.463200 \\ \mathrm{H} & 7.211300 & 1.977400 & -1.969200 \\ \mathrm{~N} & 5.397000 & 2.854500 & -1.328300 \\ \mathrm{H} & 5.145300 & 3.615000 & -0.635900 \\ \mathrm{C} & 4.637800 & 1.661300 & -0.917100 \\ \mathrm{H} & 4.719500 & 1.483600 & 0.160800 \\ \mathrm{H} & 5.031300 & 0.781700 & -1.442900 \\ \mathrm{C} & 3.191000 & 1.917600 & -1.255600 \\ \mathrm{H} & 2.542700 & 1.089100 & -0.928200 \\ \mathrm{H} & 2.868500 & 2.817800 & -0.716300 \\ \mathrm{C} & 4.839100 & 7.092300 & 4.015400 \\ \mathrm{H} & 5.485000 & 7.985300 & 3.960500 \\ \mathrm{H} & 5.106300 & 6.479800 & 4.876600 \\ \mathrm{H} & 3.804700 & 7.396200 & 4.183900 \\ \mathrm{~N} & 3.067500 & 2.173700 & -2.703300 \\ & 1.773800 & 2.775500 & -3.075600 \\ \mathrm{H} & 1.025100 & 1.995200 & -3.282500 \\ \mathrm{H} & 1.988500 & 3.356200 & -2.224500 \\ & & 3.669200 & -4.283500\end{array}$




$\begin{array}{lccc}\mathrm{H} & 1.032700 & 4.127800 & -4.597300 \\ \mathrm{H} & 2.376400 & 3.082700 & -5.121600 \\ \mathrm{~N} & 3.000000 & 4.682000 & -3.956200 \\ \mathrm{H} & 3.550300 & 4.872000 & -4.795300 \\ \mathrm{C} & 2.437300 & 5.973200 & -3.494400 \\ \mathrm{H} & 1.893500 & 6.462400 & -4.316600 \\ \mathrm{H} & 3.299800 & 6.596000 & -3.226800 \\ \mathrm{C} & 1.488700 & 5.867800 & -2.366100 \\ \mathrm{O} & 1.979200 & 5.469100 & -1.152800 \\ \mathrm{C} & 0.153700 & 6.122000 & -2.249900 \\ \mathrm{H} & -0.494400 & 6.458100 & -3.048700 \\ \mathrm{C} & -0.197500 & 5.883600 & -0.888100 \\ \mathrm{H} & -1.169600 & 5.995900 & -0.429100 \\ \mathrm{C} & 0.941300 & 5.480300 & -0.256500 \\ \mathrm{C} & 1.291900 & 5.041100 & 1.125800 \\ \mathrm{H} & 1.235500 & 3.947100 & 1.222700 \\ \mathrm{H} & 0.580900 & 5.458300 & 1.847600 \\ \mathrm{~N} & 2.656700 & 5.424300 & 1.468100 \\ \mathrm{H} & 3.294700 & 5.117200 & 0.701900 \\ \mathrm{C} & 2.858400 & 6.868000 & 1.626700 \\ \mathrm{H} & 2.406400 & 7.432100 & 0.795800 \\ \mathrm{H} & 2.367000 & 7.190900 & 2.555300 \\ \mathrm{C} & 4.353900 & 7.111200 & 1.661200 \\ \mathrm{H} & 4.584600 & 8.180300 & 1.784000 \\ \mathrm{H} & 4.793600 & 6.753100 & 0.726300 \\ \mathrm{C} & 3.277200 & 0.943300 & -3.474300 \\ \mathrm{H} & 2.572800 & 0.163000 & -3.143200 \\ \mathrm{H} & 3.148200 & 1.148800 & -4.537300 \\ \mathrm{H} & 4.302200 & 0.588300 & -3.361200 \\ \mathrm{Br} & 5.316800 & 2.828200 & -5.374700 \\ \mathrm{Br} & 5.813700 & 5.753400 & -2.714700 \\ \mathrm{Cu} & 4.556900 & 3.650200 & -2.975200 \\ \mathrm{~F} & 4.775100 & 4.600600 & 0.461300\end{array}$


Table S4. Cartesian coordinates (in $\AA$ ) calculated with density functional theory (DFT) using the M06L meta-GGA functional for the chloride complex of $\mathbf{L}$ in the gas phase.

$\begin{array}{lccc}\mathrm{Br} & 3.238900 & 6.521600 & 5.512900 \\ \mathrm{Br} & 2.080700 & 3.404300 & 4.183900 \\ \mathrm{Cu} & 3.678500 & 5.103400 & 3.461000 \\ \mathrm{~N} & 5.325100 & 6.290200 & 2.775800 \\ \mathrm{C} & 6.577700 & 5.576800 & 3.128200 \\ \mathrm{H} & 7.400500 & 6.294900 & 3.255500 \\ \mathrm{H} & 6.850500 & 4.922700 & 2.298700 \\ \mathrm{C} & 6.374300 & 4.771700 & 4.401300 \\ \mathrm{H} & 7.298800 & 4.233100 & 4.661300 \\ \mathrm{H} & 6.129400 & 5.452100 & 5.226100 \\ \mathrm{~N} & 5.220100 & 3.880000 & 4.237800 \\ \mathrm{H} & 4.766800 & 3.744300 & 5.139200 \\ \mathrm{C} & 5.488200 & 2.520000 & 3.705700 \\ \mathrm{H} & 5.948100 & 1.891000 & 4.482100 \\ \mathrm{H} & 4.503500 & 2.098100 & 3.456800 \\ \mathrm{C} & 6.384100 & 2.453800 & 2.533700 \\ \mathrm{O} & 5.955500 & 3.004200 & 1.361600 \\ \mathrm{C} & 7.596300 & 1.858400 & 2.336200 \\ \mathrm{H} & 8.170700 & 1.335200 & 3.088900 \\ \mathrm{C} & 7.923100 & 2.033400 & 0.959400 \\ \mathrm{H} & 8.803000 & 1.682000 & 0.438300 \\ \mathrm{C} & 6.898200 & 2.742000 & 0.404400 \\ \mathrm{C} & 6.589800 & 3.285300 & -0.938600 \\ \mathrm{H} & 6.528000 & 4.380000 & -0.914100 \\ \mathrm{H} & 7.389500 & 3.034200 & -1.643100 \\ \mathrm{~N} & 5.308000 & 2.791000 & -1.479500 \\ \mathrm{H} & 4.606900 & 2.795600 & -0.712100 \\ \mathrm{C} & 5.411200 & 1.395600 & -1.938900 \\ \mathrm{H} & 5.835100 & 0.747100 & -1.157100 \\ \mathrm{H} & 6.088000 & 1.378600 & -2.805600 \\ \mathrm{C} & 4.025100 & 0.926100 & -2.312500 \\ \mathrm{H} & 4.051100 & -0.083800 & -2.741800 \\ \mathrm{H} & 3.404600 & 0.907000 & -1.410300 \\ \mathrm{C} & 5.376400 & 7.649700 & 3.331500 \\ \mathrm{H} & 6.186200 & 8.218800 & 2.849000 \\ \mathrm{H} & 5.529100 & 7.603600 & 4.409800 \\ \mathrm{H} & 4.425200 & 8.160700 & 3.175700 \\ \mathrm{~N} & 3.429600 & 1.879700 & -3.282300 \\ & 2.044200 & 2.227600 & -2.914300 \\ \mathrm{H} & 1.387700 & 1.343800 & -2.981400 \\ \mathrm{H} & 1.534300 & 3.346400 & -3.793400 \\ & & & \\ \mathrm{H} & & & \end{array}$




$\begin{array}{lccc}\mathrm{H} & 1.337300 & 3.006200 & -4.817500 \\ \mathrm{~N} & 2.524100 & 4.449300 & -3.798800 \\ \mathrm{H} & 2.925700 & 4.538100 & -4.733800 \\ \mathrm{C} & 1.934700 & 5.763900 & -3.470300 \\ \mathrm{H} & 1.214400 & 6.078300 & -4.242100 \\ \mathrm{H} & 2.768300 & 6.477200 & -3.471800 \\ \mathrm{C} & 1.211300 & 5.812200 & -2.178700 \\ \mathrm{O} & 1.821400 & 5.322700 & -1.058000 \\ \mathrm{C} & 0.040900 & 6.421800 & -1.832400 \\ \mathrm{H} & -0.647600 & 6.899400 & -2.516800 \\ \mathrm{C} & -0.058200 & 6.340700 & -0.414700 \\ \mathrm{H} & -0.843800 & 6.731000 & 0.217100 \\ \mathrm{C} & 1.041300 & 5.657600 & 0.015800 \\ \mathrm{C} & 1.494100 & 5.245300 & 1.371600 \\ \mathrm{H} & 1.209400 & 4.210300 & 1.598200 \\ \mathrm{H} & 1.002500 & 5.886100 & 2.112900 \\ \mathrm{~N} & 2.952300 & 5.297000 & 1.565800 \\ \mathrm{H} & 3.308000 & 4.473200 & 1.054400 \\ \mathrm{C} & 3.603400 & 6.517000 & 1.059300 \\ \mathrm{H} & 3.438400 & 6.667000 & -0.011200 \\ \mathrm{H} & 3.184600 & 7.376600 & 1.600200 \\ \mathrm{C} & 5.081300 & 6.364800 & 1.315900 \\ \mathrm{H} & 5.660800 & 7.174600 & 0.847800 \\ \mathrm{H} & 5.415600 & 5.427800 & 0.858100 \\ \mathrm{C} & 3.512900 & 1.327800 & -4.635200 \\ \mathrm{H} & 2.876300 & 0.431800 & -4.724300 \\ \mathrm{H} & 3.219200 & 2.069100 & -5.380000 \\ \mathrm{H} & 4.550700 & 1.077000 & -4.859300 \\ \mathrm{Br} & 5.610300 & 3.828600 & -5.261400 \\ \mathrm{Br} & 5.076200 & 6.038400 & -2.201100 \\ \mathrm{Cu} & 4.380100 & 3.772900 & -2.997100 \\ \mathrm{Cl} & 2.908200 & 2.260900 & 0.587100\end{array}$


Table S5. Cartesian coordinates (in $\AA$ ) calculated with density functional theory (DFT) using the M06L meta-GGA functional for the bromide complex of $\mathbf{L}$ in the gas phase.

$\begin{array}{lccc}\mathrm{Br} & 2.615400 & 6.992500 & 4.771400 \\ \mathrm{Br} & 2.152600 & 3.491700 & 4.405600 \\ \mathrm{Cu} & 3.723200 & 5.147900 & 3.499100 \\ \mathrm{~N} & 5.391300 & 6.318300 & 2.796100 \\ \mathrm{C} & 6.630400 & 5.583700 & 3.142500 \\ \mathrm{H} & 7.471500 & 6.282100 & 3.261600 \\ \mathrm{H} & 6.885600 & 4.917400 & 2.318000 \\ \mathrm{C} & 6.420600 & 4.789000 & 4.420600 \\ \mathrm{H} & 7.322400 & 4.203200 & 4.655900 \\ \mathrm{H} & 6.240100 & 5.476400 & 5.255700 \\ \mathrm{~N} & 5.222200 & 3.950200 & 4.283000 \\ \mathrm{H} & 4.791200 & 3.806200 & 5.193300 \\ \mathrm{C} & 5.435200 & 2.578500 & 3.737000 \\ \mathrm{H} & 5.880500 & 1.937100 & 4.510700 \\ \mathrm{H} & 4.433600 & 2.190000 & 3.498800 \\ \mathrm{C} & 6.316500 & 2.486100 & 2.558700 \\ \mathrm{O} & 5.901900 & 3.061700 & 1.394000 \\ \mathrm{C} & 7.499100 & 1.838400 & 2.347900 \\ \mathrm{H} & 8.055900 & 1.286200 & 3.093100 \\ \mathrm{C} & 7.819800 & 2.003600 & 0.969000 \\ \mathrm{H} & 8.677000 & 1.613800 & 0.437600 \\ \mathrm{C} & 6.822500 & 2.759100 & 0.426300 \\ \mathrm{C} & 6.517900 & 3.309400 & -0.912500 \\ \mathrm{H} & 6.424900 & 4.401100 & -0.874300 \\ \mathrm{H} & 7.331800 & 3.090600 & -1.610800 \\ \mathrm{~N} & 5.258600 & 2.786800 & -1.483900 \\ \mathrm{H} & 4.552100 & 2.740000 & -0.724000 \\ \mathrm{C} & 5.421000 & 1.410100 & -1.983900 \\ \mathrm{H} & 5.843200 & 0.751300 & -1.210000 \\ \mathrm{H} & 6.119400 & 1.446100 & -2.832300 \\ \mathrm{C} & 4.063100 & 0.907400 & -2.410400 \\ \mathrm{H} & 4.138600 & -0.078200 & -2.885900 \\ \mathrm{H} & 3.428600 & 0.817600 & -1.521000 \\ \mathrm{C} & 5.466200 & 7.673000 & 3.358500 \\ \mathrm{H} & 6.336400 & 8.203200 & 2.940500 \\ \mathrm{H} & 5.544300 & 7.625600 & 4.446500 \\ \mathrm{H} & 4.551600 & 8.223400 & 3.138800 \\ \mathrm{~N} & 3.445600 & 1.881600 & -3.346800 \\ & 2.066800 & 2.211500 & -2.937600 \\ \mathrm{H} & 1.418300 & 1.321600 & -2.996400 \\ \mathrm{H} & 1.519800 & 3.336600 & -3.784700 \\ & & 3.517300 & -1.882600 \\ \mathrm{H} & & \\ \mathrm{H} & & \end{array}$




$\begin{array}{lccc}\mathrm{H} & 1.291500 & 3.007400 & -4.805800 \\ \mathrm{~N} & 2.499500 & 4.448000 & -3.805500 \\ \mathrm{H} & 2.873600 & 4.549100 & -4.749300 \\ \mathrm{C} & 1.905000 & 5.754500 & -3.450200 \\ \mathrm{H} & 1.165600 & 6.070300 & -4.203100 \\ \mathrm{H} & 2.731800 & 6.475400 & -3.460000 \\ \mathrm{C} & 1.208800 & 5.775000 & -2.144000 \\ \mathrm{O} & 1.854400 & 5.287800 & -1.041800 \\ \mathrm{C} & 0.030400 & 6.349000 & -1.766500 \\ \mathrm{H} & -0.683300 & 6.817600 & -2.431200 \\ \mathrm{C} & -0.039500 & 6.245700 & -0.348500 \\ \mathrm{H} & -0.820800 & 6.608600 & 0.304300 \\ \mathrm{C} & 1.085500 & 5.587100 & 0.052100 \\ \mathrm{C} & 1.587400 & 5.172800 & 1.389400 \\ \mathrm{H} & 1.316400 & 4.134800 & 1.622900 \\ \mathrm{H} & 1.123000 & 5.808900 & 2.154100 \\ \mathrm{~N} & 3.046700 & 5.241000 & 1.537600 \\ \mathrm{H} & 3.426700 & 4.444800 & 1.009900 \\ \mathrm{C} & 3.654000 & 6.499700 & 1.077500 \\ \mathrm{H} & 3.482900 & 6.689100 & 0.013300 \\ \mathrm{H} & 3.201000 & 7.315100 & 1.659900 \\ \mathrm{C} & 5.138900 & 6.406200 & 1.334900 \\ \mathrm{H} & 5.681300 & 7.251100 & 0.885500 \\ \mathrm{H} & 5.518800 & 5.495600 & 0.860100 \\ \mathrm{C} & 3.498700 & 1.362900 & -4.714400 \\ \mathrm{H} & 2.857500 & 0.471300 & -4.812900 \\ \mathrm{H} & 3.190200 & 2.122600 & -5.434400 \\ \mathrm{H} & 4.531200 & 1.116400 & -4.965000 \\ \mathrm{Br} & 5.671700 & 3.817000 & -5.241800 \\ \mathrm{Br} & 5.065100 & 6.041100 & -2.241400 \\ \mathrm{Cu} & 4.377300 & 3.777300 & -3.030800 \\ \mathrm{Br} & 2.846600 & 1.886400 & 0.762800\end{array}$


Table S6. Cartesian coordinates (in $\AA$ ) calculated with density functional theory (DFT) using the M06L meta-GGA functional for the iodide complex of $\mathbf{L}$ in the gas phase.

$\begin{array}{lrrr}\mathrm{Br} & 0.962000 & 6.321900 & 4.073300 \\ \mathrm{Br} & 3.106000 & 3.859400 & 5.291500 \\ \mathrm{Cu} & 2.776200 & 4.865800 & 3.122800 \\ \mathrm{~N} & 4.722200 & 6.096900 & 3.028500 \\ \mathrm{C} & 6.099600 & 5.554600 & 3.012300 \\ \mathrm{H} & 6.802800 & 6.402000 & 3.134400 \\ \mathrm{H} & 6.270700 & 5.121800 & 2.020500 \\ \mathrm{C} & 6.400300 & 4.478700 & 4.047000 \\ \mathrm{H} & 7.495100 & 4.437200 & 4.165600 \\ \mathrm{H} & 5.994300 & 4.770400 & 5.025600 \\ \mathrm{~N} & 5.893500 & 3.180500 & 3.663300 \\ \mathrm{H} & 5.128300 & 2.879600 & 4.254600 \\ \mathrm{C} & 6.848800 & 2.138100 & 3.408800 \\ \mathrm{H} & 7.649000 & 2.039000 & 4.173600 \\ \mathrm{H} & 6.294700 & 1.188800 & 3.424900 \\ \mathrm{C} & 7.527500 & 2.274400 & 2.088700 \\ \mathrm{O} & 6.738000 & 2.662300 & 1.046900 \\ \mathrm{C} & 8.780900 & 2.002600 & 1.623700 \\ \mathrm{H} & 9.619600 & 1.673200 & 2.222200 \\ \mathrm{C} & 8.754500 & 2.215400 & 0.210700 \\ \mathrm{H} & 9.570300 & 2.101100 & -0.489700 \\ \mathrm{C} & 7.490700 & 2.625100 & -0.091900 \\ \mathrm{C} & 6.777800 & 3.121200 & -1.295200 \\ \mathrm{H} & 6.767100 & 4.218400 & -1.322600 \\ \mathrm{H} & 7.257800 & 2.786900 & -2.220800 \\ \mathrm{~N} & 5.365100 & 2.696200 & -1.323800 \\ \mathrm{H} & 4.953900 & 2.942200 & -0.415600 \\ \mathrm{C} & 5.210100 & 1.244200 & -1.508200 \\ \mathrm{H} & 5.650500 & 0.680200 & -0.673600 \\ \mathrm{H} & 5.754500 & 0.979200 & -2.425300 \\ \mathrm{C} & 3.731600 & 0.945700 & -1.631000 \\ \mathrm{H} & 3.545200 & -0.131000 & -1.757300 \\ \mathrm{H} & 3.231700 & 1.257700 & -0.708400 \\ \mathrm{C} & 4.536600 & 6.945800 & 4.211600 \\ \mathrm{H} & 5.326700 & 7.715700 & 4.267100 \\ \mathrm{H} & 4.548700 & 6.339100 & 5.120000 \\ \mathrm{H} & 3.558000 & 7.431700 & 4.174000 \\ \mathrm{~N} & 3.168800 & 1.719900 & -2.750600 \\ \mathrm{C} & 1.808300 & 2.204300 & -2.493700 \\ \mathrm{H} & 1.079100 & 1.376600 & -2.447600 \\ \mathrm{H} & 1.817000 & 2.696900 & -1.512500 \\ \mathrm{C} & 1.408000 & 3.206300 & -3.562900 \\ \mathrm{H} & 0.528500 & 3.758500 & -3.221500 \\ & & & \end{array}$




$\begin{array}{lccc}\mathrm{H} & 1.129600 & 2.704300 & -4.498800 \\ \mathrm{~N} & 2.525500 & 4.148500 & -3.799700 \\ \mathrm{H} & 3.000700 & 3.899100 & -4.670500 \\ \mathrm{C} & 2.118000 & 5.549000 & -3.941900 \\ \mathrm{H} & 1.448700 & 5.683300 & -4.808000 \\ \mathrm{H} & 3.035700 & 6.115400 & -4.149300 \\ \mathrm{C} & 1.460400 & 6.108400 & -2.729300 \\ \mathrm{O} & 1.542400 & 5.401400 & -1.571700 \\ \mathrm{C} & 0.846200 & 7.304700 & -2.501300 \\ \mathrm{H} & 0.648200 & 8.068800 & -3.240100 \\ \mathrm{C} & 0.575600 & 7.355900 & -1.104800 \\ \mathrm{H} & 0.119800 & 8.163300 & -0.548400 \\ \mathrm{C} & 1.018300 & 6.180900 & -0.572400 \\ \mathrm{C} & 1.137500 & 5.655300 & 0.799200 \\ \mathrm{H} & 0.823700 & 4.606700 & 0.859600 \\ \mathrm{H} & 0.517600 & 6.233000 & 1.488600 \\ \mathrm{~N} & 2.532400 & 5.694200 & 1.319500 \\ \mathrm{H} & 3.106500 & 5.156700 & 0.657400 \\ \mathrm{C} & 3.105400 & 7.049200 & 1.398000 \\ \mathrm{H} & 3.056600 & 7.542300 & 0.416100 \\ \mathrm{H} & 2.500400 & 7.617600 & 2.114600 \\ \mathrm{C} & 4.551700 & 6.912100 & 1.807000 \\ \mathrm{H} & 5.017200 & 7.904200 & 1.930000 \\ \mathrm{H} & 5.079700 & 6.410100 & 0.989200 \\ \mathrm{C} & 3.256000 & 0.956400 & -3.992500 \\ \mathrm{H} & 2.568000 & 0.093400 & -3.977000 \\ \mathrm{H} & 3.034300 & 1.584500 & -4.858700 \\ \mathrm{H} & 4.280100 & 0.606100 & -4.136100 \\ \mathrm{Br} & 5.562200 & 3.344100 & -4.904100 \\ \mathrm{Br} & 4.684000 & 5.852500 & -1.663300 \\ \mathrm{Cu} & 4.225700 & 3.622100 & -2.704300 \\ \mathrm{I} & 2.702600 & 2.455800 & 1.771200\end{array}$


